\title{
Aspectos da Gramática do Português: InVESTIGaÇõEs Minimalistas
}

\author{
(Aspects of Portuguese Grammar: Minimalist Analyses)
}

\author{
Marcus Vinicius LunguinHO \\ (Universidade de São Paulo) \\ Rozana Reigota NAVES \\ (Universidade de Brasília) \\ Eloisa Silva Pilati \\ (Universidade de Brasília) \\ Poliana Camargo RABelo \\ (Universidade de Brasília) \\ Helena Guerra VICENTE \\ (Universidade Católica de Brasília)
}

ABSTRACT: This is a compilation of the last five post-graduate research projects directed by Lucia Lobato. Our goal is to exemplify two recurring issues in Lobato's work: (i) the emphasis on lexical features and structural features and (ii) the study of compositionality. Considering data mainly from Brazilian Portuguese, we focus on the following phenomena: Effects of aspectual features on Merge within the VP and on (un) availability of causative and psych alternations, subject inversion as an instance of locative inversion, covert and overt object shift through (spec, AgroP), and control within inflected and non-inflected infinitival clauses.

KEY-WORDS: aspectual features; word order; movement of constituents; control.

RESUMO: Este artigo é uma compilação dos últimos cinco trabalbos de pós-graduação orientados por Lucia Lobato. Nossa meta é exemplificar dois temas recorrentes na linha de pesquisa desta lingüísta: (i) ênfase em traços lexicais e estruturais e (ii) composicionalidade. Considerando principalmente dados do português do Brasil, analisamos: efeitos de traços aspectuais em Concatenaçães dentro do VP e na (in) determinação de alternâncias causativa e psicológica; inversão do sujeito como um tipo de inversão locativa; alçamento manifesto ou não do objeto para (spec, AgroP); controle nas orações infinitivas flexionadas e não-flexionadas.

PALAVRAS-CHAVE: traços aspectuais; ordem das palavras; movimento de constituintes; controle.

D.E.L.T.A., 23:esp., 2007 (147-191) 


\section{Introdução}

Este artigo representa um esforço conjunto dos últimos orientandos de Mestrado e de Doutorado da professora Lucia Lobato no sentido de dar a conhecer à comunidade lingüística em geral, por meio das temáticas desenvolvidas e das análises propostas, um pouco do que vinha sendo a abrangência do trabalho desta respeitada lingüista. As análises que serão apresentadas aqui, frutos do trabalho de orientação de Lucia Lobato, deixam transparecer três das características mais marcantes da vida acadêmica dessa pesquisadora: busca pelo desvendar dos fatos empíricos, independência teórica e profundo respeito a todos os pesquisadores e tipos de trabalhos desenvolvidos em lingüística.

O texto que se segue pretende, de uma maneira pouco trivial (já que seria muito complicado definir uma única temática comum aos últimos cinco trabalhos orientados por Lobato), apresentar aquilo que, no entendimento dos seus orientandos, caracteriza a linha de pesquisa desenvolvida por ela na Universidade de Brasília. Pelo menos dois eixos dessa linha poderão ser identificados: a ênfase dada a um tipo de abordagem baseada em traços lexicais e estruturais (especialmente os traços aspectuais) e a idéia de que a sintaxe trabalha com a combinação desses traços (o que resulta na noção de composicionalidade).

O artigo tem a seguinte estrutura: na Seção 2, será apresentado o trabalho de Lunguinho (2005), a respeito da ordem dos verbos aspectuais do português do Brasil; a Seção 3 traz a pesquisa de Naves (2005) a respeito da relevância dos traços aspectuais para a distinção entre verbos psicológicos e causativos que admitem alternância sintática e verbos que não admitem esse tipo de alternância; a Seção 4 retoma o debate sobre a ordem verbo-sujeito (VS) no português do Brasil (PB), com base nos trabalhos de Pilati (2002) e (2006); a análise de Vicente (2006) para os fenômenos de alçamento de objeto e de flutuação de quantificador no PB é apresentada na Seção 5; por fim, a Seção 6 traz a discussão, encontrada em Rabelo (2004), a respeito das construções de controle e sua relação com os infinitivos flexionado e não-flexionado do português brasileiro. 


\section{A sintaxe dos verbos aspectuais do português Brasileiro: questões de ordem}

Os temas da auxiliaridade e da ordem das palavras sempre foram objeto de grande interesse por parte de Lucia Lobato (cf. Lobato 1971, 1975), e foram retomados por Lunguinho (2005), que avança no sentido de explorar em detalhes o papel dos traços dos verbos aspectuais e dos seus complementos na derivação da ordem desses verbos.

\subsection{Dos verbos aspectuais}

Os verbos aspectuais têm recebido inúmeras classificações na literatura. Na Gramática Tradicional, esses verbos recebem os nomes de verbos auxiliares aspectuais, verbos aspectuais ou verbos acurativos.

Em estudos lingüísticos, classificam-se esses verbos como operadores aspectuais (cf. Oliveira 2003; Oliveira, Cunha, Matos \& Gonçalves 2001; Cunha 2004) ou aspectualizadores (cf. Verkuyl 1999; Wachowicz 2006; Wachowicz \& Cavalli 2006). Nesses casos, a ênfase é dada à característica desses verbos de poderem modificar/restringir a estrutura temporal das eventualidades que lhe servem de complemento.

O fato de os verbos aspectuais não terem sofrido perda de traços semânticos é um dado que se apresenta na literatura para diferenciá-los dos verdadeiros auxiliares (cf. Castilho 1968, 1984, 2002; Lobato 1975; Longo 1991; Longo \& Campos 2002; Laca 2004; Wachowicz 2006; Wachowicz \& Cavalli 2006). Com base nessa informação, é possível levantar as seguintes características dos verbos aspectuais: (i) são verbos lexicais; (ii) projetam na sintaxe um sintagma verbal; (iii) impõem restrições de seleção ao(s) seu(s) argumento(s). ${ }^{1}$

Dizer que os aspectuais são verbos lexicais dá conta do fato de eles: (i) conservarem sua interpretação semântica original e (ii) trazerem para a derivação traços formais. Tratar esses verbos como verbos lexicais conduz obrigatoriamente à característica de, na sintaxe, eles projetarem um sintagma verbal e não serem inseridos em núcleos funcionais da estrutura

\footnotetext{
1 Há trabalhos que apontam uma quarta característica desses verbos, que é a de serem verbos inacusativos (cf. Gonçalves 1996; Corso 2002; Boff 2003).
} 
oracional. ${ }^{2}$ Por fim, caracterizar os verbos aspectuais como itens de natureza lexical ainda implica dizer que eles podem selecionar argumento(s) e podem também impor restrições semânticas e sintáticas a esse(s) argumento(s). Combinando essas características, Lunguinho (2005), ao analisar a questão da ordem entre os verbos aspectuais, trabalha com a hipótese de que esses verbos podem impor restrição quanto ao tipo aspectual do seu complemento.

\subsection{Verbos aspectuais e restrições de seleção}

Como a hipótese de trabalho apresentada no final da Subseção anterior se fundamenta na idéia de tipos aspectuais de eventos, a análise dos verbos aspectuais realizada por Lunguinho (2005) leva em conta propostas, encontradas na literatura, que tratam dos eventos sob o ponto de vista de sua natureza aspectual.

Uma dessas propostas é a de Vendler (1967), que apresenta uma tipologia de eventos divididos em quatro categorias aspectuais, tendo por base dois parâmetros: (i) presença/ausência de término lógico (telicidade) e (ii) transcurso ou não em dado espaço de tempo (duração). Da combinação desses parâmetros, resultam as quatro categorias aspectuais vendlerianas: processos, processos culminados, culminações e estados. ${ }^{3}$

Os processos são uma categoria aspectual que apresenta transcurso em um dado espaço de tempo, mas sem término lógico:

(1) a. Ontem choveu muito

b. Nadei muito

Os processos culminados transcorrem em um dado espaço de tempo e apresentam sempre um término logicamente definido:

(2) a. O menino desenhou um quadrado

b. A velhinha atravessou a faixa de pedestres

\footnotetext{
2 A esse respeito, ver Cinque (1999), que propõe serem os verbos aspectuais itens de natureza funcional inseridos em núcleos funcionais específicos da estrutura oracional.

3 Essa é a tradução que tem sido dada pelos lingüistas portugueses (cf. Mateus et alii 2003) aos termos activities, accomplishments, achievements, states, inicialmente propostos por Vendler.
} 
As culminações são eventos que não transcorrem em espaço de tempo, mas apresentam término logicamente definido:

(3) a. O prédio desabou

b. A vidraça quebrou

Os estados são uma categoria aspectual que não transcorre em um período específico de tempo e não apresenta término lógico:

(4) a. A casa está bagunçada

b. A professora tem um carro

Além das características inicialmente propostas por Vendler, os estudiosos apresentam mais uma, a dinamicidade, que separa os estados das demais categorias aspectuais (cf. Smith 1983, 1991; Talmy 1985; Tenny \& Pustejovsky 2000): ${ }^{4}$

Tabela 1: Traços Semânticos das Classes Aspectuais

\begin{tabular}{|l|c|c|c|}
\hline Categorias aspectuais & Transcurso no tempo & Telicidade & Dinamicidade \\
\hline Estados & - & - & - \\
\hline Processos Culminados & + & + & + \\
\hline Culminações & - & + & + \\
\hline Processos & + & - & + \\
\hline
\end{tabular}

Lunguinho (2005) adota os traços apresentados na Tabela 1 para analisar os verbos aspectuais. Associar o traço de dinamicidade aos outros dois (tradicionalmente evocados na descrição das categorias aspectuais vendlerianas) possibilita incluir no seu trabalho uma noção que tem sido apontada na literatura como relevante para explicar as possibilidades de combinação

4 Foi-nos apontado que, em abordagens mais recentes, essa característica é que, de fato, distingue os estados dos processos. Apesar de ambas as classes envolverem transcurso no tempo (duração), apenas os processos são dinâmicos, isto é, apresentam mudança de estado em seu transcurso. 
dos verbos aspectuais entre si: a noção de fase. Essa noção se refere às etapas de um evento no seu decorrer e está intimamente relacionada a estados de coisas dinâmicos (cf. Castilho 1968, 1984; Dascal 1982; Costa 1997; Oliveira 2003; Cunha 1998, 2004; Laca 2004).

Uma vez definidos os traços relevantes, podem ser apresentadas as propriedades de seleção dos verbos auxiliares aspectuais do Português Brasileiro. Por limitações de espaço, serão apresentados apenas os aspectuais comesar, continuar e terminar. ${ }^{5}$

\subsubsection{Comeşar}

Os dados relativos a comeşar, em (5) abaixo, permitem a Lunguinho (2005) concluir que, em relação às propriedades de seleção, esse verbo só aceita combinar-se com eventos que pertencem às classes de processo, processo culminado e culminação. $\mathrm{O}$ traço comum a essas classes aspectuais é o traço [+dinâmico], o que mostra que há nelas uma estrutura em que podemos vislumbrar fases internas. Dessa maneira, temos que comę̧ar seleciona um complemento com valor aspectual $[+$ dinâmico $]$.

(5) a. Ontem começou a [chover]

b. Comecei a [nadar]

c. O menino começará a [desenhar um quadrado]

d. A velhinha começa a [atravessar a faixa de pedestres]

e. O prédio começará a [desabar]

f. A vidraça começou a [quebrar]

g. *A casa começa a [estar bagunçada]

h. *A professora começou a $[\text { ter um carro }]^{6}$

\footnotetext{
5 Análises de outros verbos aspectuais podem ser encontradas em Oliveira, Cunha, Matos \& Gonçalves (2001) e em Lunguinho (2005).

6 Foi-nos apontado que alguns predicados (estativos) do tipo stage-level podem ser admitidos como complementos de comeşar: Comecei a [ter dores de cabeşa cada vez mais freqüentes]. Essa possibilidade se deve a "um mecanismo comum de validar estados em contextos de eventualidades desde que a interpretação mais característica da classe seja modificada parcialmente". No caso apresentado, o estado é marcado por habitualidade, o que nos leva a assimilá-lo a um processo. Já predicados (estativos) do tipo individual-level, por não admitirem essa modificação facilmente, não aparecem na posição de complemento de começar: *A Maria começou a [ser alta]. Por questões de espaço, não se discutiu em detalhes a complementação de comeşar. A esse respeito, ver Dascal (1982), Cunha (1998; 2004), Boff (2003) e Lunguinho (2005).
} 


\subsubsection{Continuar}

No tocante à seleção aspectual, continuar (exemplos em (6)) só aceita coocorrer com predicados [+dinâmicos], donde o autor conclui que continuar seleciona complementos [+dinâmicos].

(6) a. Continuou a [chover]

b. A menina continuou a [nadar]

c. A menina continuará [desenhando um quadrado]

d. A velhinha continua [atravessando a faixa de pedestres]

e. O prédio continuou [desabando]

f. A vidraça continua [quebrando]

g. *A casa continua a [estar bagunçada]

h. *A professora continua [tendo um carro] ${ }^{7}$

\subsubsection{Terminar}

De acordo com os exemplos em (7), tem-se que terminar, um verbo que marca o ponto final de um evento (ou que restringe a eventualidade a seu ponto terminal), só se combina com predicados que tenham em sua estrutura temporal interna um ponto final logicamente definido: processos culminados e culminações. Estados e processos, por compartilharem a característica de não terem ponto final na sua estrutura temporal, são excluídos da posição de complemento desse verbo. Terminar é, pois, um verbo que seleciona aspectualmente complementos cujo traço [ + télico $]$ esteja presente.

(7) a. *Terminou de [chover]

b. *Pedro terminou de $[\text { nadar }]^{8}$

\footnotetext{
7 Assim como aconteceu com a complementação de comeşar (nota anterior), alguns predicados estativos podem se combinar com continuar: Continuo [sabendo francês], Continuamos [sendo os alunos mais altos da escola] e Pedro continua [tendo tempo para ligar para todo mundo na hora do almoco]. Devido ao espaço, esses casos não serão discutidos aqui, de modo que a hipótese ora apresentada foi simplificada. Para uma discussão de casos como esses, ver referências sugeridas na nota anterior.

8 Nesse exemplo, o predicado [Pedro nadar $]$ deve ser interpretado como um processo. Essa oração torna-se gramatical num contexto em que o falante e o ouvinte sabem que Pedro deve fazer um dado percurso e que ele completou todo esse percurso. Nesse caso, a interpretação do predicado passa de processo para processo culminado por meio de uma espécie de coerção de tipo aspectual (cf. de Swart 1998). Uma questão a ser investigada em trabalho futuro é como se formalizam coerções de tipo, sem violar a Condição de Inclusividade (cf. Chomsky 1995), em um modelo de gramática em que a sintaxe fornece a estrutura que será interpretada no componente semântico.
} 
c. O menino terminou de [desenhar um quadrado]

d. A velhinha terminou de [atravessar a faixa de pedestres]

e. O prédio terminou de [desabar]

f. A vidraça terminou de [quebrar]

g. *A casa terminou de [estar bagunçada]

h. *A professora terminou de [ter um carro]

\subsection{A natureza aspectual dos constituintes formados a partir de um verbo} aspectual: seu papel na explicação da ordem entre os verbos aspectuais

Na Subseção anterior, ficou demonstrado que cada um dos verbos aspectuais analisados se caracteriza por impor um certo tipo de restrição ao seu complemento e que essa restrição é de natureza aspectual. Em síntese:

(8) Verbos aspectuais: restrições de seleção

a. começar e continuar: selecionam complemento [+ dinâmico]

b. terminar: seleciona complemento [ + télico]

Se os traços aspectuais do complemento são importantes para a análise da sintaxe de complementação dos verbos aspectuais, então, para entender a ordem entre os auxiliares aspectuais, é necessário saber que traços aspectuais o constituinte formado a partir de um verbo aspectual tem. Os dados abaixo trazem a interação dos constituintes formados a partir de um verbo aspectual com sintagmas preposicionais:

(9) a. *Começo a ler o livro por uma hora

b. Começo a ler o livro em uma hora

c. Começo a ler o livro às duas horas

(10) a. *A menina termina de fazer a prova por uma hora

b. A menina termina de fazer a prova em uma hora

c. A menina termina de fazer a prova às duas horas

(11) a. *Essa mulher continua lendo o livro por duas horas

b. *Essa mulher continua lendo o livro em duas horas

c. ??Essa mulher continua lendo o livro às duas horas

Os testes acima revelam que os sintagmas formados a partir de começar e terminar comportam-se de maneira semelhante. Como não aceitam com- 
binar-se com sintagmas [por $X$ tempo], que assinalam o transcurso do evento no tempo, conforme (9a) e (10a), a conclusão é a de que os constituintes formados por começar e terminar não transcorrem no tempo. A gramaticalidade dos exemplos com o sintagma em X tempo mostra que esses constituintes ou apresentam transcurso no tempo ou apresentam termino lógico ou os dois. Como eles não transcorrem no tempo, o que eles podem apresentar é o final logicamente definido; tal fato pode ser notado a partir da interpretação semântica das orações (9b) e (10b): o que o sintagma em X horas está assinalando é o momento em que se inicia a leitura do livro e o momento em se chega ao final do evento de fazer a prova. O sintagma pontual às duas horas marca a culminação dos eventos em análise e reforça a hipótese de que esses eventos são instantâneos e não apresentam transcurso no tempo. Os sintagmas formados por comęar e terminar são, portanto, do tipo aspectual culminação.

Os sintagmas formados a partir do aspectual continuar rejeitam os sintagmas preposicionais. ${ }^{9}$ Logo, a conclusão é a de que esses sintagmas se comportam como eventualidades sem transcurso no tempo nem término definido, ou seja, que os sintagmas formados a partir de continuar são aspectualmente estados. Em síntese:

(12) Traços aspectuais dos constituintes formados a partir de um aspectual

a. Começar e terminar formam um constituinte cuja interpretação aspectual é de culminação.

b. Continuar forma um constituinte cuja interpretação aspectual é de estado.

Aliando esses traços aspectuais aos traços de seleção dos verbos em estudo resulta o seguinte quadro de previsões de ordem entre os aspectuais:

(13) Verbos aspectuais: previsão de ordem

a. Os verbos aspectuais começar e continuar podem ser complementados por um constituinte formado pelos auxiliares começar e terminar;

b. O verbo terminar pode ser complementado por um constituinte formado pelos auxiliares começar e terminar.

9 Há a possibilidade de os sintagmas preposicionais se referirem ao evento encaixado, ocasião em que as seqüências em análise podem ser tomadas como gramaticais. Essa situação é excluída da argumentação, pois o que está sendo analisado é a possibilidade de esses sintagmas se referirem a todo o constituinte formado por continuar e o seu complemento. 
Segundo o que foi proposto, o verbo comesar deve ser gramatical quando seu complemento for encabeçado pelos verbos começar ou terminar, verbos que, como já foi dito, constroem sintagmas [ + dinâmicos]:

(14) a. *Eu comecei a [começar a estudar]

b. Paulo começou a [terminar de digitar sua tese]

c. *Eu comecei a [continuar a esperar pelo ônibus]

A agramaticalidade prevista foi confirmada: comęar não aceita ser complementado pelos sintagmas formados a partir do verbo continuar. Isso se dá porque continuar forma um constituinte portador do traço [-dinâmico] que, na posição de complemento de comeşar, gera uma incompatibilidade de traços (cf. Chomsky 1995) que leva a derivação ao fracasso. A gramaticalidade de terminar como complemento de comeşar também se confirma. Um problema que surge é a inesperada agramaticalidade de começar quando complementado por um sintagma introduzido por começar, fato que será explicado mais adiante.

Quanto ao verbo continuar, em (15), os fatos também se dão como previsto. Esse verbo só permite complementos [+ dinâmicos]: complementos formados a partir de começar e terminar são gramaticais; complementos [-dinâmicos] não são tolerados, o que exclui a ordem continuar-continuar.

(15) a. A moça continua [começando a sua tese (mas até agora não fez nada)]

b. Continuo [terminando minha parte do trabalho]

c. * Carla continua [continuando escrevendo sua carta]

O aspectual terminar, por sua vez, seleciona um complemento $[+$ télico]. Segundo a análise aqui apresentada, os únicos verbos que formam constituintes télicos são aqueles formados a partir de terminar e começar. Logo, terminar só pode combinar-se com esses dois aspectuais:

(16) a. *Terminei de [continuar fazendo o jantar]

b. Terminei de [começar a fazer meu trabalho para o livro]

c. *Terminei de [terminar de fazer meu trabalho para o livro]

A proposta apresentada fornece a previsão correta para a agramaticalidade de (16a), assim como uma explicação para a gramaticalidade de (16b). Um problema para a proposta aqui desenvolvida concerne ao exem- 
plo (16c), que é agramatical mesmo tendo um sintagma $[+$ télico $]$ como complemento de terminar. Esse exemplo e o exemplo (14a) serão tratados na próxima Subseção.

\subsection{Incompatibilidades sintáticas e efeitos de interface}

Pela proposta desenvolvida na Subseção anterior, seria natural que as seqüências de auxiliares em (17) fossem gramaticais, pois os complementos dos verbos matrizes terminar e começar têm os traços que esses verbos selecionam:

(17) a. *Terminei de [terminar de fazer meu trabalho para a revista]

b. *Eu comecei a [começar a fazer meu trabalho para a revista]

Nesses dados, terminar tem em seu complemento uma instância do mesmo verbo terminar, e começar também é complementado pelo mesmo verbo comę̧ar. A hipótese levantada por Lunguinho (2005) é a de que é justamente esse fato que explica o porquê de essas sentenças serem agramaticais.

A agramaticalidade dos exemplos (17) pode ser explicada por meio da idéia-chave do Programa Minimalista (cf. Chomsky 1995) de que os itens lexicais entram na derivação munidos de traços e de que a computação sintática é resultado direto da manipulação desses traços. Os verbos aspectuais trazem seus traços para a derivação e, nos casos observados, ocorre duas vezes na derivação um mesmo traço (uma redundância de informação), uma vez que tanto o constituinte complemento do verbo aspectual quanto o próprio complexo formado por esse aspectual e o seu complemento portam os mesmos traços. A proposta de Lunguinho (2005) é a de que, se dois aspectuais têm os mesmos traços e eles são concatenados (merged) em um dado estágio da derivação, esse estágio se configura como um passo supérfluo, no sentido de trazer um traço que já havia sido introduzido nessa derivação, como mostra o esquema (18):

(18) aspectual $\left._{2}[\mathrm{~F}]\left[\operatorname{aspectual}_{1}[\mathrm{~F}]\right]\right]$

A Numeração referente aos dados (17) envolve duas instâncias de um verbo aspectual, portando, segundo a análise desenvolvida anteriormente, 
um mesmo traço, aqui simbolizado por $[\mathrm{F}]$. Pelo esquema acima, quando o verbo aspectual mais baixo entra na derivação, ele está com todos os seus traços, entre eles $[\mathrm{F}]$. Em um estágio imediatamente posterior ao da inserção desse aspectual, é selecionada da Numeração a outra ocorrência do aspectual, o aspectual ${ }_{2}$, que é concatenado como em (18). Por hipótese, ao chegar à interface Concepto-Intensional (C-I), apenas os traços de um dos aspectuais serão interpretados. Os traços do outro aspectual não receberão interpretação relevante nessa interface, logo, haverá uma violação do Princípio de Interpretação Plena (cf. Chomsky 1995), uma vez que há traços que não receberam interpretação na interface. Lunguinho (2005) propõe que seqüências em (17) sejam agramaticais devido à falta de efeito na interface.

A evidência em favor dessa hipótese explicativa vem do seguinte exemplo:

(19) O secretário acabou de acabar de imprimir os formulários

Esse exemplo mostra que os aspectuais em questão não portam exatamente os mesmos traços e a pista para isso é sua interpretação semântica: a oração (19) é interpretada como "agorinha/nesse exato momento o secretário terminou de imprimir os formulários”, em que o primeiro acabar tem a leitura de passado recente e o segundo acabar tem a leitura de término de um evento.

Uma vez que os traços dos itens lexicais dão as instruções para os sistemas de interface, a conclusão automática é que essa diferença de leituras para acabar, no exemplo em exame, é o resultado de diferenças, em termos de traços, entre esses itens. Lunguinho (2005) propõe então que os dois verbos acabar, apesar de apresentarem os mesmos traços fonéticos, entram na derivação da sentença (19) com dois conjuntos de traços semânticos diferentes. Por serem traços diferentes, todos têm efeito na interface, isto é, recebem interpretação apropriada, fato esse que licencia a seqüência. A existência de exemplos como esse permite crer que a hipótese formulada acima em relação à redundância de traços na interface parece estar no caminho certo e pode ser útil na explicação de certos fatos relativos à ordem dos verbos auxiliares. 


\section{A alternância sintática dos predicados psicológicos e causativos}

Um outro trabalho que enfatiza a importância dos traços aspectuais dos predicados para a configuração sintática é Naves (2005), a respeito da alternância verbal observada nos chamados predicados psicológicos (classe de verbos caracterizada semanticamente pela propriedade de descrever estados da mente ou mudanças nos estados da mente (Levin, 1993)) e nos predicados causativos em geral. ${ }^{10}$

O tema da alternância sintática, que ultrapassa as classes dos predicados psicológicos e causativos (cf. Levin 1993) tem sido muito discutido recentemente. Algumas análises encontradas na literatura (cf. Belletti \& Rizzi 1988, 1992; Hale \& Keyser 1998, 1999; Arad 1998; Bennis 2004) apresentam uma base sintática para tratar o problema, enquanto outras (cf. Grimshaw 1990; Pesetsky 1995; Bouchard 1995; Reinhart 2000, 2001; Cançado 2002) apontam para a importância dos aspectos semânticos envolvidos nesse tipo de fenômeno. Naves (2005) apresenta uma proposta de análise da alternância psicológica e causativa em termos de traços aspectuais, que estariam na base da interface sintaxe-semântica.

Dado esse contexto, o objetivo desta Seção é demonstrar a relevância do papel dos traços aspectuais na distinção dos verbos psicológicos e causativos que podem ou não podem participar do fenômeno da alternância sintática.

\subsection{Sobre o fenômeno da alternância sintática}

O fenômeno da alternância sintática está relacionado ao fato de um certo tipo de verbos poder projetar mais de uma estrutura na sintaxe. No caso dos predicados psicológicos e causativos, uma das estruturas é transitiva (cf. (20a) e (21a)) e a outra é intransitiva (cf. (20b) e (21b)). A alternância sintática tem como resultado que os argumentos dos verbos são

\footnotetext{
10 A idéia de estudar predicados psicológicos e predicados causativos num mesmo trabalho se deve ao fato de que a literatura nessa área tem apontado para a possibilidade de um certo grupo de predicados psicológicos, na estrutura transitiva, receber uma interpretação causativa (sobre esse assunto, ver por exemplo, Grimshaw 1990; Croft 1993).
} 
mapeados em posições diferentes em cada uma das estruturas, como ilustram as sublinhas nos pares de exemplos abaixo.

(20) a. A ameaça de greve geral preocupa o governo

b. O governo se preocupa com a ameaça de greve geral

(21) a. João balançou a corda

b. A corda balançou

Uma das questões interessantes sobre os predicados psicológicos e causativos, no que se refere à alternância, é que nem todos os verbos que se caracterizam como psicológicos ou causativos podem alternar, o que está exemplificado em (22) e (23):

(22) a. O governo teme a ameaça de greve geral

b. * A ameaça de greve geral (se) teme com o governo

(23) a. O caçador matou o leão

b. *O leão matou

Partindo do pressuposto de que os verbos pertencentes a uma mesma classe de predicados compartilham entre si certos componentes de significado (o que permite explicar a eficiência com que as crianças adquirem o sistema lingüístico), o trabalho de Naves (2005) lida com o desafio de conciliar o fato empírico representado pelas alternâncias verbais com o fato teórico de que deve haver princípios gerais que norteiam o processo de aquisição de língua.

Nesse sentido, em relação às alternâncias psicológica e causativa, uma das questões cruciais é definir que propriedades (traços) desses predicados distinguem os verbos que admitem alternância dos verbos que não admitem. A hipótese desenvolvida pela autora é a de que os traços relevantes para explicar o fenômeno em foco estão relacionados ao predicado (verbo e seu argumento interno), uma vez que esse tipo de alternância sintática se caracteriza pelo fato de a seqüência $[\mathrm{V}+$ argumento interno] (por exemplo, em $O$ governo se preocupa (20b) e $A$ corda balançou (22b)) poder ser licenciada como uma sentença da língua. Esse fato está representado em (24):

(24) a. Argumento externo $-\mathrm{V}-$ Argumento interno $\rightarrow$ Sentença transitiva

b. $\quad \ldots \ldots \ldots \ldots-\mathrm{V}-$ Argumento interno $\rightarrow$ Sentença intransitiva 


\subsection{Traços abstratos relevantes para a alternância sintática em foco}

Nesta Subseção, serão apresentados os traços abstratos que se mostraram relevantes para a distinção entre verbos psicológicos e causativos alternantes e verbos psicológicos e causativos não-alternantes, no trabalho de Naves (2005). Será demonstrado também que a possibilidade de alternância é dada composicionalmente, pela combinação de dois traços abstratos, a saber, telicidade e afetação.

\subsubsection{Classes aspectuais}

Com relação às classes aspectuais, definidas como na proposta de Vendler (1967), é possível constatar que apenas os predicados psicológicos e causativos que se classificam como processos culminados (25) e como culminações (26) admitem a alternância sintática, ao passo que predicados psicológicos e causativos que se classificam como estados (27) e como processos (28) não admitem a alternância.

(25) Processos culminados
a. A cozinheira derreteu a manteiga
A manteiga derreteu
b. Os patrões acalmaram os manifestantes
Os manifestantes se acalmaram

(26) Culminações
a. O menino quebrou a vidraça
A vidraça (se) quebrou
b. Os palhaços assustaram as crianças
As crianças (se) assustaram (com os palhaços)

(27) Estados
a. João sabe inglês
*Inglês (se) sabe
b. O governo teme a inflação
*O governo (se) teme (com a inflação)

(28) Processos
a. João quebra côco na praia
*Côco quebra na praia 
b. Algumas sociedades adoram vários deuses ${ }^{11}$

*Vários deuses (se) adoram

Em termos de traços abstratos, isso significa dizer que o traço de telicidade (cf.Tabela 1, Subseção 2.2), que distingue processos culminados e culminações, de um lado, de estados e atividades, de outro lado, é relevante para explicar a distinção entre verbos que alternam e verbos que não alternam.

Apesar disso, há verbos que formam predicados télicos (culminações e processos culminados) e, ainda assim, não admitem a alternância, o que está representado em (29):

(29) a. João atingiu o topo da montanha

(Culminação)

*O topo da montanha (se) atingiu

b. Os pescadores construíram uma jangada

(Processo culminado)

*Uma jangada (se) construiu

A conclusão é a de que, embora o traço de telicidade seja necessário para explicar a diferença entre os predicados que alternam e os predicados que não alternam, esse traço não é suficiente. Para explicar a agramaticalidade dos dados em (29), é preciso recorrer, segundo Naves (2005), a um outro traço abstrato - o da afetação.

\subsubsection{Afetação}

Ao traço de afetação (do inglês, affectedness) têm sido atribuídas, na literatura, duas acepções: a de mudança de estado e a de delimitação de evento. $^{12}$

Os dados em (29), repetidos em (30a) e (30b) abaixo, são exemplos de sentenças em que o elemento na posição de objeto é interpretado como um

11 Adorar, neste exemplo, está sendo tomado numa interpretação física, equivalente a 'realizar rituais de adoração'. Para mais detalhes sobre a interpretação física dos predicados psicológicos, ver Arad (1998).

12 Sobre a interpretação de afetação como delimitação de evento, ver Tenny $(1987,1989)$. 
delimitador do evento (em outras palavras, o topo da montanha e uma janga$d a$ representam o ponto final dos eventos denotados pelos verbos atingir e construir, respectivamente). Nessa acepção, a alternância sintática não é permitida.

Por outro lado, os exemplos (30c) e (30d) mostram que, nas sentenças em que o elemento na posição de objeto é interpretado como afetado, na acepção de mudança de estado, a alternância sintática é possível, de forma que a conclusão é a de que o traço de mudança de estado se mostra, portanto, relevante para explicar a distinção entre os verbos psicológicos e causativos que alternam e os que não alternam.

(30) a. João atingiu o topo da montanha *O topo da montanha (se) atingiu

b. Os pescadores construíram uma jangada *Uma jangada (se) construiu

c. Os meninos quebraram a vidraça A vidraça (se) quebrou

d. Os palhaços assustaram as crianças As crianças (se) assustaram
(Delimitação do evento)

(Delimitação do evento)

(Mudança de estado)

(Mudança de estado)

Uma preocupação presente em Naves (2005) diz respeito à necessidade de explicar o fenômeno da alternância sintática dos predicados psicológicos e causativos com base no menor número possível de traços abstratos, o que possibilitaria uma economia descritiva e explicativa, nos moldes do que sugere o Programa Minimalista (cf. Chomsky 1995). Sendo assim, seria preciso verificar se o traço afetação, no sentido relevante (de mudança de estado), não seria suficiente para explicar o fenômeno em questão. Os dados mostram que a resposta é negativa: existem predicados que, embora recebam a interpretação de mudança de estado do objeto, não admitem alternância (o exemplo está em (31)).

(31) a. João quebra côco na praia

b. *Côco quebra na praia

\subsection{Alternância Sintática e Composicionalidade}

Na Subseção anterior, ficou demonstrada a participação dos traços de telicidade e de mudança de estado (afetação) na identificação dos predica- 
dos psicológicos e causativos que admitem a alternância sintática. ${ }^{13}$ Ficou também nítido que esses traços não podem ser tomados independentemente um do outro, uma vez que isso reduz o poder explicativo do fenômeno.

O que os fatos empíricos exemplificados pelos dados (25)-(31) deixam transparecer é que os traços telicidade (de natureza aspectual) e mudança de estado (de natureza semântica) atuam composicionalmente no fenômeno da alternância sintática. Naves(2005) propõe a seguinte análise para os predicados psicológicos e causativos:

$\begin{aligned} \text { (32) a. } & \mathrm{V}_{\text {[télico] }}+\mathrm{NP}_{[+ \text {mudança de estado] }} \rightarrow \checkmark \text { alternância } \\ \text { b. } & \mathrm{V}_{\text {[télico] }}+\mathrm{NP}_{[\text {- mudança de estado] }} \rightarrow * \text { alternância } \\ \text { c. } & \mathrm{V}_{\text {[atélico] }} \rightarrow * \text { alternância }\end{aligned}$

Segundo essa proposta, o traço aspectual de telicidade é vislumbrado primeiro pelo componente sintático da gramática. Se um dado verbo psicológico ou causativo não forma predicados télicos, então a possibilidade de alternância é automaticamente descartada e só a estrutura transitiva pode ser projetada (32c). Por outro lado, se um verbo psicológico ou causativo pode formar predicados télicos, então o traço semântico de mudança de estado é acessado. Nesse último caso, se o objeto pode ser interpretado como tendo sofrido uma mudança de estado, a alternância pode acontecer (32a); em contrapartida, se esse objeto não sofre mudança de estado, a alternância é agramatical (32b). ${ }^{14}$

13 Os traços relativos ao elemento na posição de sujeito das sentenças transitivas também foram analisados por Naves (2005). Esses traços, embora se mostrassem relevantes para explicar o mapeamento dos argumentos dos predicados psicológicos e causativos, não se mostraram relevantes para distinguir os predicados alternantes dos não-alternantes. Isso se explica pelo fato de que o traço do argumento externo pode não ser acessado na computação, já que esse elemento não ocorre na estrutura alternante intransitiva dos referidos predicados e há um pressuposto de que uma estrutura não deriva sintaticamente da outra (sendo, antes, geradas independentemente). Por falta de espaço, essas questões não serão detalhadas aqui.

14 Foi-nos apontado que certos dados do português parecem criar problemas para a generalização proposta em (32a). Trata-se de predicados aparentemente télicos, em que o argumento interno possui o traço mudança de estado, mas que não admitem a alternância, tais como os exemplos:

(i) a. O Paulo lavou o prato

b. *O prato (se) lavou

(ii) a. A Maria limpou o banheiro

b. *O banheiro (se) lavou 
O fato de haver uma hierarquia entre traços aspectuais (acessados primeiro pela sintaxe) e traços semânticos (hierarquia que, no trabalho de Naves (2005), explica inclusive o mapeamento dos argumentos dos predicados psicológicos e causativos nas estruturas sintáticas alternantes) também era uma idéia defendida pela professora Lucia Lobato (c.p.).

\section{Aspectos sintáticos e semânticos das orações com ordem verbo-sujeito (VS) no português do Brasil}

A questão da ordem das palavras foi também objeto de estudo de Pilati (2002) e (2006), que investiga a sintaxe das orações declarativas com ordem verbo-sujeito (VS) no português do Brasil (PB) e em outras línguas, com os propósitos, respectivamente, de (i) examinar contextos favorecedores da ordem verbo-sujeito no PB e identificar características sintáticas (tipo de verbo, ocorrência de elementos adverbiais e operadores de foco) e semânticas (tipo de sujeito, se referencial ou não, definido ou indefinido) desse tipo de oração e (ii) explicar o licenciamento das orações declarativas com ordem verbo-sujeito (VS), identificadas em Pilati (2002).

\subsection{Fatos sobre a ordem VS}

A tendência nos estudos gerativistas (cf. Figueiredo Silva 1996; Kato 2000) é a de considerar que a ordem VS no PB é licenciada apenas com

\footnotetext{
Com relação a esses dados, dois fatos podem ser apontados: primeiro, o de que verbos como lavar e limpar formam comumente predicados interpretados como processos (portanto, não télicos) e, segundo, o de que os argumentos internos o prato e $o$ banheiro podem receber uma interpretação de delimitação do evento, já que os eventos de lavar e limpar cessam uma vez que o prato e o banheiro estejam, respectivamente, lavado e limpo.

Naves considera que, em dados como esses, o que parece acontecer é uma interação dos traços relevantes para a análise da alternância com o sistema tempo-modo-aspecto, que acaba resultando numa interpretação de telicidade (o pretérito perfeito dos verbos em (i) e (ii) indica que o evento foi concluído, ou seja, teve um final lógico). Essa interação com o sistema tempo-modo-aspecto poderia explicar também por que (i-b) e (ii-b) são agramaticais, ao passo que (iii) e (iv) são gramaticais, pelo menos em algumas variedades do português do Brasil:

(iii) O prato está lavando

(iv) O banheiro está limpando

A interação entre os traços relevantes para o fenômeno da alternância psicológica/causativa e o sistema tempo-modo-aspecto é um ponto que ainda precisa ser melhor investigado.
} 
verbos inacusativos, como em (33a). As ocorrências de VS com verbos inergativos, como em (33b), são consideradas "residuais" e as orações que apresentam verbos transitivos são consideradas agramaticais, como (33c).
(33) a. Chegou o trem
(Verbo inacusativo)
b. ?Telefonou o cliente
(Verbo inergativo)
c. *Assinou a carta o chefe do departamento
(Verbo transitivo)

No entanto, estudos funcionalistas (cf. Naro \& Votre 1999) mostram que verbos transitivos podem ocorrer em construções com a ordem VS, apesar de serem pouco freqüentes:

(34) a. Nem sempre ganha o favorito (VT usado intransitivamente)
b. Se você chegar em Pernambuco, ele não fala a mesma coisa que fala o baiano

(VT usado com o objeto manifesto em forma de qu $+\mathrm{O}$ )

Pilati (2002) encontra outros contextos em que a ordem VS ocorre no PB: com verbos leves (35a); em narrações esportivas (35b) e (35c) em contextos estipulativos (contextos em que são transmitidas instruções, como manuais de jogos). Ela verifica também que estudos quantitativos constatam que esse tipo de ordem tem baixa freqüência no PB

(35) a. Hoje tomou posse o novo Ministro da Cultura
b. Arriscou o chute Diego Tardelli
c. Vence a partida o jogador que tiver mais pontos

Pilati (2002) constata que a ocorrência de VS está restrita a determinados tipos de contextos pragmáticos. Segundo a interpretação de Nascimento (1984), grande parte das orações com ordem VS recebe "interpretação de lista”, ou seja, são orações que definem, sempre, uma relação de $[+/-$ inclusão] num dado grupo de referência:

(36) Dos alunos da UnB, viajou a Maria

Ainda em relação ao contexto de ocorrência, Naro \& Votre (1999) apontam que a ordem VS é usada em contextos discursivos em que o sujeito (S) não veicula informação relacionada ao tópico do discurso e é, portanto, uma oração que traz elementos que estão fora do fluxo informacional 
do discurso, fato que pode ser verificado pela comparação do grau de adequação das orações em (37) e (38). O que pode ser constado nesses exemplos é que a oração (37a) é considerada adequada como continuação de (37b), por não veicular informações sobre o tópico do discurso, no caso a festa. Já a oração (38b), é considerada inadequada em relação a (38a), porque nesse contexto Maria é o tópico do discurso, portanto não poderia ocorrer na ordem VS.

(37) a. Fui numa festa ótima ontem

b. Entre os convidados estava a Maria

(38) a. Estou procurando a Maria

b. \#Entre os convidados estava a Maria

c. A Maria estava entre os convidados

(Adaptado de Bresnan, 1994)

Em resumo, Pilati (2002) chega às seguintes constatações:

(i) A ordem VS apresenta uma ocorrência bem mais baixa que SV;

(ii) Verbos inacusativos ocorrem com menos restrições que as demais classes;

(iii) Verbos inergativos e transitivos são mais restritos;

(iv) Verbos transitivos podem ser licenciados na ordem VOS;

(v) A estrutura argumental do verbo pode influenciar o licenciamento de VS (cf. Kato \&Tarallo, 2003)

(vi) A ocorrência da ordem VS no PB está delimitada por contextos pragmáticos específicos.

\subsection{O licenciamento das oraçees declarativas com ordem verbo-sujeito}

Para tentar explicar o fator que desencadeia o licenciamento das orações com ordem VS no PB, Pilati (2006) analisa dados do inglês, italiano, chichewa e português do Brasil. Entre as conclusões e hipóteses da pesquisa sobre a gramática do PB e das línguas em geral, podem-se citar: (i) a codificação de foco é um fenômeno sintático, isto é, um fenômeno ligado a aspectos como: possibilidades de movimento do verbo, relações de escopo 
(c-comando), categorização sintática de informações lexicais e formas de atribuição de Caso; e (ii) a interpretação das orações em relação ao tipo de foco (se informacional ou se identificacional, por exemplo) também é o resultado de um processo sintático. Por questões de espaço, este artigo tratará apenas do percurso que levou Pilati (2006) à conclusão de que as características gramaticais de certas orações licenciadas na ordem VS em PB podem ser explicadas ao se tratar tais orações como "inversões locativas", ou seja, como orações que apresentam um elemento locativo ou temporal, nulo ou manifesto, na seguinte ordem (LOC/ TEMP)-V-S.

A análise de Pilati (2006) para o PB se apóia na proposta de Pinto (1997) para o italiano, segundo a qual o licenciamento da ordem VS nessa língua está relacionado a fatores sintáticos (seleção de um argumento locativo) e à aplicação da regra de Acento Nuclear (NSR) (cf. Cinque 1993; Reinhart 1995). Pilati (2006) constata que as orações com ordem VS do PB podem ser consideradas tipos de inversões locativas como as presentes no italiano (cf. Pinto 1997), porque: (i) são freqüentes com verbos inacusativos (39a); (ii) ocorrem geralmente com PPs locativos ou temporais à esquerda, com interpretação dêitica (locativa ou temporal), como em (39b,d); e (iii) apresentam restrições a verbos transitivos, mas os licenciam com expressões idiomáticas e em contextos de narração concomitante (cf. Belletti 2001; Pilati 2002).

(39) a. Primeiro chegaram os móveis

b. Já almoçou todo mundo

c. *Em hotéis dormiu a Maria

d. Neste hotel dormiu a Maria

Para fundamentar a argumentação em favor da análise das orações do tipo (PP)VS do PB como inversões locativas, Pilati (2006) se baseia nas características dessas orações em estudos de outros pesquisadores, a respeito de línguas como o italiano, inglês e o chichewa. ${ }^{15}$

Bresnan \& Kanerva (1989) mostram que a inversão locativa no chichewa compartilha características sintáticas e semânticas com as inversões locativas de línguas como o inglês e defendem que as inversões locativas do

15 Aqui serão apresentadas apenas as propostas utilizadas por Pilati (2006) na argumentação em favor de se considerar a ordem VS como um tipo de inversão locativa. 
chichewa são construções que ocorrem quando há um elemento locativo (NP que recebe um prefixo obrigatório para sujeitos) preposto ao verbo, e o sujeito é posposto ao verbo, como em (40b). São observadas também inversões locativas com verbos transitivos, apesar de haver restrições (41b).

(40) a. Chi-tsîme chi-li ku mu-dzi

o-poço está na cidade

'O poço está na cidade'

b. Ku mu-dzi ku-li chi-tsîme

na cidade está o-poço

'Na cidade está o poço'

(41) a. A-lenje a-na-túmíz-a ma-zira kw-á á-tsíkana os-caçadores mandaram ovos para as-garotas

'Os caçadores mandaram ovos para as garotas'

b. *Kw-á á-tsíkana ku-túmíz-a a-lenje ma-zira

para as-garotas mandaram os-caçadores ovos

'Para as garotas mandaram ovos os caçadores'

Bresnan (1994) estabelece uma comparação entre as inversões locativas do inglês e do chichewa e mostra que as duas línguas são semelhantes em vários aspectos, mas que selecionam diferentes categorias para a codificação de informações dos elementos locativos/temporais (em inglês são PPs (como em (42) e em chichewa são NPs (ver dado (40)). Para Bresnan, por apresentar um estatuto categorial diferente, o elemento locativo ocupa posições estruturais diferentes nas duas línguas.

(42) Among the guests was sitting my friend Rose

entre the convidados estava sentado meu amigo Rose

'Entre os convidados estava sentada minha amiga Rose'

Levin \& Rappaport (1995) mostram que a inversão locativa está estritamente ligada às propriedades de seleção temática dos verbos e que, portanto, não pode ser considerada um diagnóstico para inacusatividade. Entre as características sintáticas apontadas pelas autoras estão: (i) essas orações têm a estrutura PP VP NP; (ii) o PP inicial é um elemento com referência locativa ou direcional; (iii) podem ser licenciadas com verbos inergativos ou inacusativos, embora nem todos os verbos inacusativos sejam licenciados em inversões locativas, como mostram os dados (43), de L\&R (1995); 
(iv) podem ser licenciadas com verbos transitivos, quando o verbo é formado por frases fixas, ou expressões idiomáticas, como take place "ocorrer" e take root "estabelecer-se". 16

(43) a. *On the top floor of the skyscraper broke many windows em o último andar de o arranha-céu quebrou muitas janelas

'No último andar do arranha-céu quebraram muitas janelas'

b. *On the streets of Chicago melted a lot of snow em as ruas de Chicago derreteu muita de neve

'Nas ruas de Chicago derreteu um monte de neve'

\subsection{Caracterização sintática das orações com inversão locativa no $P B$}

Seguindo os mesmos parâmetros apresentados na comparação entre o inglês e o chichewa, Pilati (2006) analisa as orações com ordem (PP)VS do $\mathrm{PB}$, mostrando que:

(i) Nas orações com ordem VS do PB, os elementos locativos/temporais das orações com ordem VS são elementos preposicionados - PPs (44), embora haja contextos em que essa posição pré-verbal pode ser ocupada por elementos dêiticos como aí ou com operadores de foco como também, só (45):

(44) a. Primeiro almoço eu, depois você

b. Na sexta viaja o Paulo

(45) a. Aíliga a D. Maria...

b. Também participa do programa a Professora Renata

c. Só não gostaram do passeio as crianças pequenas

(ii) Dada a natureza preposicional desses elementos, não há concordância entre o PP e o verbo da oração (46b) e a tendência é haver concordância entre o verbo e o sujeito pós-verbal (46a). ${ }^{17}$

16 Para Levin \& Rappaport (1995), a possibilidade de ocorrência ou não de inversões locativas está diretamente relacionada à função discursiva desse tipo de construção. É por causa dessa função discursiva que verbos transitivos são encontrados em inversões locativas.

17 Devido à redução do paradigma flexional no $\mathrm{PB}$, há variedades dialetais em que a concordância não é morfologicamente marcada, mesmo quando o sujeito está em posição pré-verbal (cf. Duarte 1993). 
(46) a. Primeiro falo eu

b. *Primeiro fala eu

(iii) Há a possibilidade de o elemento locativo ser nulo, mas com referência recuperada anaforicamente por elementos da situação discursiva, assim como no italiano (cf. Pinto 1997), no chichewa (cf. Bresnan \& Kanerva, 1989) e no inglês (cf. Bresnan, 1994):

(47) Lá na casa da Maria? Vixe......chegou um monte de coisa

(iv) $\mathrm{O} P B$ licencia inversões com restrições a verbos transitivos quando as orações com ordem VOS ocorrem em contextos em que o predicado $(\mathrm{V}+\mathrm{O})$ pode ser interpretado como uma informação antiga ou prevista na situação discursiva, como em $(48 \mathrm{a}, \mathrm{b})$, ou quando o predicado é formado por elementos semanticamente leves, como em (48c):

(48) a. Ganha a partida o jogador que fizer mais pontos

b. Domina a bola o jogador do Vasco

c. Também faz parte da revista o escritor Alexandre Pilati

(v) No PB, os inacusativos são licenciados com maior freqüência na ordem VS, mas nem todos os verbos considerados inacusativos licenciam a ordem VS da mesma forma. Verbos de movimento ou que tenham traços relacionados a tempo ou espaço são mais naturais no licenciamento da inversão (49a), e verbos que não possuem esse traço semântico colocam maiores restrições ao licenciamento da ordem VS, fora de um contexto específico (49b):

(49) a. Aqui chegaram as cartas

b. *Aqui avermelhou o urubu

(vi) A análise das orações com ordem (PP)VS do PB corrobora as propostas encontradas na literatura de que esse tipo de oração serve para introduzir um referente ou novo ou menos familiar no discurso, como nos exemplos (50), em que (50B) e (50C), para ocorrerem como continuação de $(50 \mathrm{~A})$ precisam de um contexto específico para serem licenciados: 
(50) A: Estou procurando minha amiga Rose

B: \#Entre os convidados de honra estava sentada Rose

C: Rose estava sentada entre os convidados de honra

Pilati (2006) trata também de orações com ordem VOS do PB, proferidas em narrações concomitantes (51), que, segundo a autora, também podem ser analisadas como tendo estrutura semelhante à da inversão locativa, mas que, devido ao contexto discursivo em que ocorrem, não apresentam obrigatoriamente um PP em posição inicial.

(51) a. Ergue o braço o juiz

b. Pega a bola o goleiro do Flamengo

Os argumentos que levam à formulação dessa análise são os seguintes: (i) o contexto discursivo dessas orações deixa evidente que a interpretação do PP locativo é dêitica, pois essas orações descrevem eventos que ocorrem quase concomitantemente à narração, não sendo necessário que o emissor expresse verbalmente nem o local (que é o campo de futebol) nem o momento em que os fatos estão ocorrendo (já que a narração é concomitante); e (ii) a mesma interpretação dêitica pode ser atribuída a orações que ocorrem em contextos previsíveis, tais como:

(52) a. Entrou o Dante

(cf. O Dante entrou (aqui /nesse lugar))

b. Morreu Fellini

(cf. Fellini acabou de morrer

Eu acabei de ouvir que Fellini morreu)

Pelos dados em (51) e (52) é possível perceber que a ausência fonológica de um elemento locativo na posição inicial não altera a interpretação das sentenças nem interfere na sua gramaticalidade. As orações com ordem VOS, portanto, podem também ser analisadas como inversões locativas.

$\mathrm{O}$ exame dos dados do $\mathrm{PB}$, em relação às propriedades das inversões locativas encontradas na literatura, permitiu a Pilati (2006) confirmar a hipótese de que as orações com ordem (PP)VS dessa língua podem ser analisadas como construções desse tipo. 


\section{Os fenômenos de alçamento do objeto e flutuação de quantificador: Constrastes Translingüísticos}

Esta Seção, que representa uma parte do trabalho de Vicente (2006), trata do fenômeno referido na literatura como flutuação de quantificador (Q-float), cuja manifestação evidencia contrastes translingüísticos relevantes para a discussão a respeito de um conjunto de propriedades das línguas em estudo - o português brasileiro ( $\mathrm{PB}$ ), o inglês e o romeno -, em particular no que se refere à estrutura oracional, uma preocupação sempre presente nas orientações e pesquisas da professora Lucia Lobato.

Neste artigo, será apresentado apenas um desses contrastes, a saber, o pressuposto - evidenciado a partir de testes com o quantificador todos - de que o $\mathrm{PB}$, ao contrário das duas outras línguas, apresenta um fenômeno a que Vicente (2006) denomina Object Shift restrito. Em relação ao inglês e ao romeno, a autora pressupõe a ocorrência de Object Shift irrestrito. ${ }^{18}$

\subsection{O fenômeno de alçamento do objeto e o quantificador todos}

O fenômeno de alçamento do Objeto (Object Shift), definido por Johnson (1991:604) como "a case of A-Movement that relocates a structurally Casemarked NP just when the verb assigning Case to that NP has been moved", foi primeiramente observado nas línguas escandinavas. A evidência mais amplamente divulgada na literatura provém de um fato do islandês, ilustrado em (53). ${ }^{19}$ Nessa língua, o fato de o objeto direto (bcekurnar), preceder a negação, (ekki, presumivelmente em $\operatorname{AgrNegP}$ ), é tradicionalmente utilizado para indicar que o objeto se moveu, de maneira manifesta, para [Spec, AgrOP] (cf. Holmberg \& Platzack 1995; Vikner 1995; Boškoviæ 1997; Holmberg 1999).

(53) [Halldór las bækurnar ${ }_{1}$ ekki [allar $\left.\left.t_{1}\right]\right\}$

Halldór leu os.livros não todos

'Halldór não leu todos os livros'

\footnotetext{
18 A decisão de tratar apenas de um dos contrastes se deve à limitação de espaço. A terminologia Object Shift irrestrito é de autoria de Vicente (2006).

19 Dado extraído de Boškoviæ (2004).
} 
Um fato do inglês, comumente utilizado como evidência a favor do movimento do objeto, é o das construções com elipse Pseudogapping (Lasnik, 1999). A hipótese de Lasnik é a de que a construção abaixo envolve elipse do VP, mas que o elemento remanescente (Bill) se desloca antes, escapando, assim, do local da elipse.

(54) Mary hired John, and Susan will hire Bill Mary contratou John e Susan vai Bill

'A Mary contratou o John, e a Susan vai contratar o Bill'

Nenhum dos testes acima, o primeiro no islandês, e o segundo no inglês, funcionaria para o $\mathrm{PB}$, já que, nessa língua, objetos nunca precedem a negação, e tampouco ocorrem construções com elipse Pseudogapping. No entanto, Vicente (2006) nota que um teste com ligação anafórica poderia fornecer evidência para a hipótese de que o movimento do objeto ocorre também no PB. Antes de tratar do PB, entretanto, será apresentado como esse tipo de teste funciona para o inglês.

Fenômenos de ligação costumam funcionar como diagnóstico de movimento de objeto. Lasnik (1999) observa que sujeitos ECM comportamse como se estivessem ocupando posições mais altas que as ocupadas por outros elementos da oração principal. ${ }^{20}$ No exemplo acima, a Condição A, segundo a qual anafóricos devem estar ligados por seu antecedente em seu domínio de ligação, foi satisfeita, e, por isso, a oração é gramatical. Se o sintagma adverbial (i.e., o adjunto during each other's trials), contendo o item (each other's), que tem de ser licenciado, está na oração mais alta, conclui-se que o sujeito ECM (two men) também deve encontrar-se na oração mais alta, ocupando uma posição mais alta que a do sintagma adverbial.

(55) The DA proved [two men to have been at the scene of the crime] o promotor provou dois bomens inf.ter estado em a cena de o crime during each other's trials durante cada outro. GEN julgamentos

'O promotor provou que os dois homens estiveram na cena do crime durante os julgamentos de um e de outro/um do outro'

20 Marcação excepcional de Caso (exceptional Case marking): situações em que o Caso do sujeito é checado em uma posição externa ao IP que o contém. 
Lasnik observa, ainda, que o comportamento dos objetos transitivos é análogo ao dos sujeitos ECM no que se refere ao posicionamento em relação ao sintagma adverbial. Em (56), a ligação entre o anafórico each other e seu antecedente, o objeto two men, é possível porque o objeto ocupa uma posição mais alta que a do anafórico, o que pressupõe o movimento do objeto para uma posição mais alta do que aquela na qual foi gerado. Essa posição mais alta seria [Spec, AgrOP].

(56) The DA accused two men during each other's trials o promotor acusou dois homens durante cada outro.GEN julgamentos

'O promotor acusou dois homens durante os julgamentos de um e de outro/ um do outro'

\subsection{Uma proposta de análise para o português do Brasil}

Em relação ao PB, Vicente (2006) observa que, também nessa língua, os objetos devem mover-se para posições mais altas na estrutura, por motivos de ligação anafórica. No exemplo (57a), se o sintagma objeto os dois homens continuasse na posição em que foi gerado, não poderia estabelecer a ligação com o anafórico de um e de outro/um do outro. Somente o movimento desse sintagma (ilustrado em (57b)) para uma posição externa ao VP explica a gramaticalidade de sentenças como essa. Entretanto, como esse tipo de evidência é controverso, Vicente (2006) opta por não utilizá-lo como prova definitiva para o fato de haver o movimento manifesto do objeto no PB. ${ }^{21,22}$

\footnotetext{
21 De acordo com Chomsky (2001, entre outros trabalhos), o movimento do objeto, pelo menos em construções envolvendo ligação anafórica, não é manifesto: "(T)-he intention of binding an anaphor is not part of the mechanism of raising". Outros autores (cf. Boškoviæ 1997, Lasnik 2000), no entanto, argumentam a favor da hipótese com movimento manifesto. É interessante notar, contudo, que Chomsky, antes resistente à idéia do movimento manifesto do objeto no inglês, também já aceita (cf. Chomsky, 2005) que 'pelo menos' construções do tipo ECM, como as apresentadas por Lasnik, entre outros autores, constituam evidência para o referido movimento. Aqui, Vicente opta por deixar a questão em aberto, já que os testes apresentados no corpo do texto, apontando evidências para o movimento manifesto do objeto no inglês (cf. Radford 1997) e no romeno (cf. Alboiu 1999), em outros tipos de construção, não se aplicam ao PB.

22 Lasnik (2000), por exemplo, argumenta que, tipicamente, movimentos encobertos somente envolvem traços formais, o que não criaria nenhuma configuração relevante de ligação.
} 
(57) a. O promotor acusou os dois homens durante os julgamentos de um e de outro/um do outro

b. Movimento do objeto, pelo menos no caso da ligação de anafórico recíproco no PB

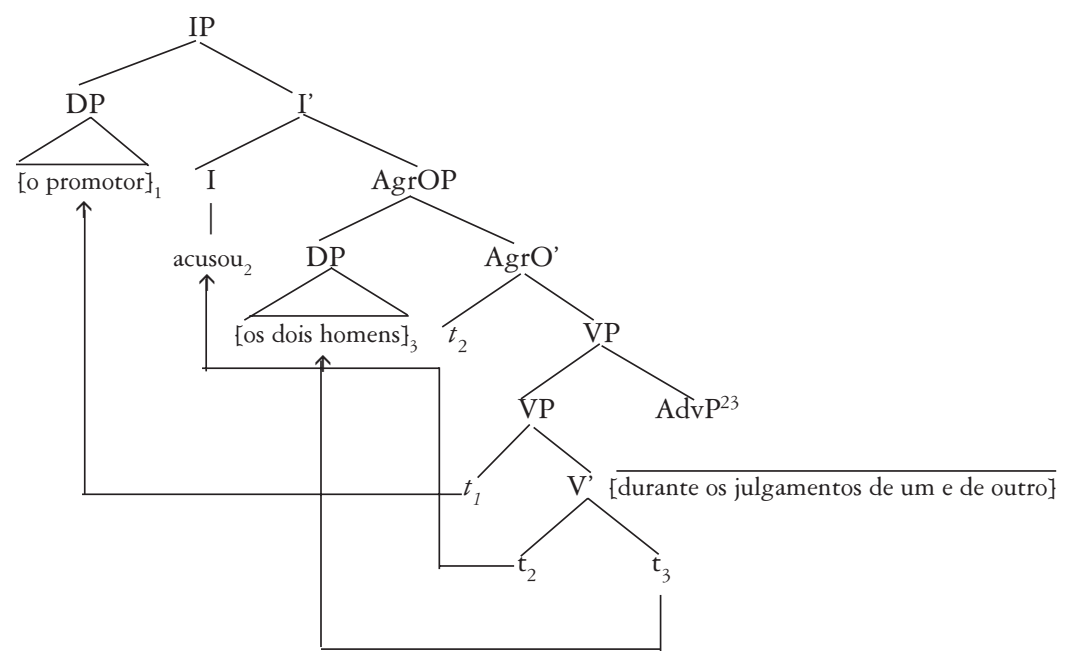

Para o inglês, a hipótese adotada pela pesquisadora é a de que, nessa língua, há, de fato, evidência para tal movimento ocorrer de forma manifesta. Vicente aceita a argumentação em Radford (1997), por exemplo, segundo a qual as diferenças sistemáticas entre a posição de CPs-complemento e DPs-complemento fornecem evidência a favor da hipótese de que DPs objeto, no inglês, movem-se abertamente para checar Caso. Os dados a seguir mostram que DPs-complemento, no inglês, ocorrem, necessariamente, adjacentes ao verbo.

(58) a. He admitted to her that he was guilty ele admitiu a ela que ele era culpado

'Ele admitiu a/para ela que era culpado'

(cf. * He admitted that he was guilt to her)

b. He admitted his guilt to her ele admitiu sua culpa a ela

'Ele admitiu a ela sua culpa ou 'Ele admitiu sua culpa a/para ela'

(cf. *He admitted to her his guilt)

23 Vale ressaltar que não se está necessariamente adotando uma hipótese de adjunção à direita. Vicente prefere não tomar partido nessa discussão, que, por si só, constituiria o objeto de uma tese. 
(59) a. He recommended to her that she should consult Cy Coe ele recomendou a ela que ela deveria consultar Cy Coe 'Ele recomendou a ela que consultasse Cy Coe' (cf. *He recommended that she should consult $\mathrm{Cy}$ Coe to her)

b. He recommended an analyst to her ele recomendou um analista a ela 'Ele recomendou a ela um analista' ou 'Ele recomendou um analista a/para ela' (cf. *He recommended to her an analyst)

De acordo com Radford (1997), com base nos dados acima, parece possível supor que complementos do tipo that-clause não carregam Caso acusativo, e, por isso, permanecem in-situ. Esse autor (1997) observa ainda que esse tipo de construção (i.e., CPs) nunca ocorre como complemento de preposições transitivas como as seguintes, em negrito:

(60) a. *I was sure of that she'd come eu estava certo de que ela.iria vir 'Eu estava certo de que ela viria'

b. *There isn't time for that we have a meal Expl é.não tempo para que nós tem uma refeição

'Não há tempo para que façamos uma refeição'

A questão é que esse tipo de evidência (além de Pseudogapping e da negação no islandês, vistos anteriormente) tampouco serve para o PB, já que, nessa língua, as posições ocupadas por DPs-complemento e CPs-complemento não são tão fixas assim, como se pode constatar nas glosas em (58)-(59). Além disso, como se pode ver nas glosas em (60), construções do tipo thatclause podem ocorrer como complemento de preposição transitiva no PB.

Outra língua que, por hipótese, como o inglês, apresenta Object Shift manifesto é o romeno. Em muitos casos, para que se tenha certeza de o movimento ter ocorrido na sintaxe aberta, é preciso que o elemento movido tenha deixado alguma pista palpável pelo caminho, como material encalhado, por exemplo, e é exatamente isso que ocorre nessa língua. $\mathrm{O}$ exemplo em Alboiu (1999:19) mostra que, no romeno, o quantificador flutuante aparece em uma posição mais baixa que a do objeto:

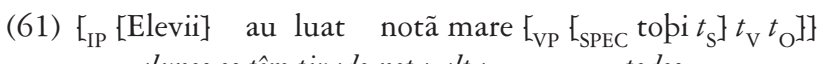
alunos.os têm tirado nota alta todos

'(Todos) os alunos tiraram (todos) notas altas' 
Pressupondo que um quantificador flutuante associado ao sujeito encontra-se adjacente ao vestígio desse sujeito (cf. Sportiche 1988), Alboiu conclui que, no exemplo acima, o objeto deve ter se deslocado por sobre a posição na qual o sujeito foi gerado. Em geral, pressupõe-se (cf. Alboiu 1999; Cornilescu 2000; Herdan 2003, 2005) que o verbo do romeno se alça a posições bem altas na estrutura sintagmática, possibilitando aos objetos sofrer até dois movimentos a partir da posição em que são gerados.

Apesar de o PB e o romeno apresentarem certas características em comum, Vicente (2006) observa que esse tipo de evidência com quantificador flutuante não pode ser estendido para o $\mathrm{PB}$, pelo fato de a contraparte de (61) ser agramatical nessa língua:

(62) *Os alunos tiraram notas altas todos

Em resumo: os testes normalmente aplicados para se diagnosticar a presença do movimento manifesto do objeto, vistos acima, dão todos resultado negativo para o PB. Vicente (2006) pressupõe, então, que o objeto do PB não se move na sintaxe aberta, ao contrário do que acontece em outras línguas, como o islandês, o inglês e o romeno. Vale salientar que é crucial para a análise dos dados do PB feita por Vicente o pressuposto, em Costa \& Galves (2002), de que o verbo dessa língua se move apenas até T. De acordo com esse estudo, não haveria, na estrutura do $\mathrm{PB}$, a possibilidade de verbos, objetos e sujeitos serem alçados a posições mais altas, como acontece no romeno. A inexistência dessa possibilidade explicaria a agramaticalidade de orações como (62).

Vicente (2006) nota, contudo, um fato curioso em relação ao PB. Enquanto os diagnósticos para os testes referidos são negativos, certos fatos dessa língua levam-na a lançar a hipótese de que complementos de verbos passivos e inacusativos - ao contrário dos complementos de verbos transitivos - sofrem movimentos intermediários, manifestos, para [Spec, AgrOP] antes de aterrissarem em sua posição final, no âmbito do sintagma flexional. No exemplo a seguir (de uma construção passiva, com ocorrência de Q-float), a pista palpável é a hipótese de o quantificador ficar encalhado, adjacente ao vestígio do complemento do verbo na passiva, que, antes de aterrissar em [Spec, IP], deve sofrer deslocamento intermediário para [Spec, AgrOP]. O dado abaixo, do PB, parece confirmar a hipótese de Radford 
(1997), segundo a qual o sujeito da passiva das línguas em geral sofreria um deslocamento intermediário para [Spec, AgrOP], pelo fato de apresentar características em comum com objetos.

(63) $\check{L}_{\mathrm{IP}}[\mathrm{Os} \text { votos }]_{3}$ foram $\left[\operatorname{todos} t_{3}\right]_{1} \operatorname{contados}_{2}\left[\left[_{\mathrm{VP}}\left[\left[_{\mathrm{V}}, t_{2} t_{1}\right]\right]\right]\right.$

Argumentação adicional em favor desse tipo de deslocamento é fornecida por Kayne (1989 apud Radford 1997), em estudo no qual observa que o verbo da passiva no francês concorda com o sujeito da superfície, (o que justificaria o movimento do verbo para o núcleo da projeção AgrOP:

(64) La décision a été prise par le sénat

a decisão foi sido tomada por o senado

'A decisão foi tomada pelo senado'

Vicente (2006) chama a atenção para a glosa, onde se nota que o mesmo argumento pode ser estendido ao PB. ${ }^{24}$ Sobre isso, Radford lembra a observação em Burzio (1986) de que os sujeitos das inacusativas e os objetos em geral compartilham algumas características. Radford (1997) argumenta que uma maneira de se captarem essas características é supor que, em um momento da derivação, o sujeito das inacusativas se move para [Spec, AgrOP], como ilustra a derivação de (65), em (66):

(65) Les écolières sont parties en Belgique as estudantes.fem são partidas em Bélgica 'As estudantes partiram para a Bélgica'

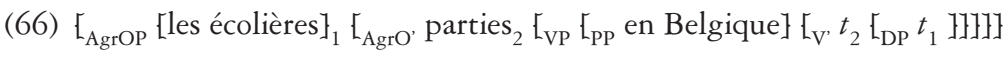

O autor argumenta que a concordância observada entre o DP les écolières e o particípio inacusativo parties é um reflexo da relação de concordância especificador-núcleo interna a AgrOP. Esse raciocínio pode ser esten-

24 Nota-se, no PB atual, uma tendência (tanto na escrita como na fala, e mesmo na língua culta) a não se observar a concordância gênero/plural em orações inacusativas e passivas apresentando a ordem VS (ver também nota 15). 
dido para os dados do PB, dizendo-se que essa língua capta os fatos de concordância observados nas passivas (rever a glosa do exemplo em (64)) e nas inacusativas (As cartas chegadas em dezembro, As batatas cozidas em água e sal).

\section{Infinitivo flexionado sob controle no português do Brasil}

Um outro tema que sempre atraiu a professora Lucia Lobato era o das chamadas construções de controle, que surgem em contextos em que há orações infinitivas e gerundivas encaixadas, como em (67), abaixo:

(67) a. João quis _ sair da aula mais cedo hoje

b. João prometeu pra sua mãe _ não comer doces antes do almoço

c. João perguntou como _ resolver o problema mais rápido

d. João foi embora sem _ se despedir de ninguém

e. João convenceu a Maria a __ sair

f. O João morreu _ esperando uma resposta do INSS

g. _Estudar é indispensável nos dias de hoje

Esse tipo de estrutura foi objeto de estudo de Rabelo (2004), cuja proposta será apresentada nesta seção.

\subsection{Construcões de controle e infinitivos}

Os exemplos de (67) apresentam as características das estruturas de controle, a saber: (i) interpreta-se um sujeito nas posições representadas pelas lacunas nos exemplos acima; (ii) esse sujeito subentendido, às vezes, é obrigatoriamente correferente com um argumento da oração matriz (cf. (67a-f)) e, outras vezes, pode ter uma interpretação arbitrária (cf. (67c) e $(67 \mathrm{~g})) ;^{25}$ (iii) os papéis temáticos do sujeito da encaixada e do sintagma nominal correferente são independentes; ${ }^{26}$ (iv) o sujeito da oração infinitiva nunca pode ser realizado foneticamente, nem por um pronome correferente:

25 O exemplo (67c) é ambíguo entre uma interpretação em que o sujeito da infinitiva recebe interpretação correferente com João e outra em que recebe uma interpretação arbitrária.

26 A independência temática entre o sujeito da infinitiva e o sintagma com o qual ele é correferente é um dos motivos para se distinguirem as estruturas de controle das estruturas de alçamento. 
(68) a. *João quis o Paulo sair da aula mais cedo hoje

b. *João ${ }_{i}$ quis ele $e_{i}$ sair mais cedo da aula hoje

Usando-se a terminologia técnica, diz-se que o sujeito nulo das orações infinitivas do tipo ilustrado em (67a-f) é controlado por um argumento da oração matriz. Esse argumento que serve de antecedente e que dá referência ao sujeito da infinitiva é chamado controlador. A oração infinitiva do tipo da ilustrada em (67c) em uma de suas interpretações e (67g) é dita de interpretação arbitrária, pois não há um controlador disponível na oração matriz e o sujeito é interpretado como um humano indeterminado, isto é, um humano de interpretação arbitrária.

As construções de controle são, então, aquelas em que as orações encaixadas infinitivas ou gerundivas possuem um sujeito obrigatoriamente nulo, que pode ser correferente com um argumento da oração matriz.

No português, além dessas construções típicas de infinitivo sem flexão, encontra-se o infinitivo flexionado, forma verbal que aparece, assim como a forma sem flexão, obrigatoriamente em orações encaixadas ((69a) versus (69b)). Em face dessa flexão do infinitivo, a oração subordinada infinitiva admite, tipicamente, tanto o sujeito lexical quanto o sujeito nulo, o que torna plausível a suposição de que, no último caso, o sujeito seja realizado pela categoria pronominal pro (69c). Devido a essas características, não se configurariam, com o infinitivo flexionado, construções de controle.

(67) a. Um secretário admitiu estarem os americanos perdendo a guerra

b. *Estarem os americanos perdendo a guerra

c. Um secretário admitiu estarem os americanos/pro perdendo a guerra

Em Rabelo (2004), entretanto, a discussão do infinitivo flexionado do português leva à conclusão de que há controle obrigatório com variação de estrutura sintática entre o infinitivo flexionado e o infinitivo não-flexiona-

Nas estruturas de alçamento apenas o verbo da oração encaixada tem um papel semântico para atribuir ao sujeito, o que permite, entre outras razões, o movimento desse argumento para a posição não-argumental de sujeito do verbo da matriz. Temos, assim, a seguinte representação (simplificada) da estrutura de alçamento:

(i) O meu chefe parece $t_{1}$ estar mais $t_{1}$ cansado hoje

Nessa estrutura, " $t$ " representa o vestígio deixado pelo sintagma nominal o meu chefe após o movimento. 
do, como mostra (70), abaixo, em que há controle obrigatório com infinitivos não-flexionado e flexionado, respectivamente.

(68) a. Ministro da Educação incentiva estudantes ${ }_{1}$ a $e_{1 / * 2}$ fazer passeatas por mais recursos

b. Ministro da Educação incentiva estudantes ${ }_{1}$ a $e_{1 /{ }_{2}}$ fazerem passeatas por mais recursos

As conclusões da pesquisa de Rabelo (2004) são decorrentes da análise dos dados exemplificados em (71)-(73), em que se verifica a alternância entre o infinitivo flexionado e não-flexionado (com sujeito nulo correferencial a um termo da oração matriz) em diferentes contextos sintáticos (notadamente, orações completivas e adverbiais).

(69) a. *Os meninos tentaram saírem

b. Os meninos tentaram sair

c. As italianas sabem serem encantadoras (cf. Lemle, 1984:183)

d. As italianas sabem ser encantadoras (cf. Lemle, 1984:183)

(70) a. Ministro da Educação incentiva estudantes a fazerem passeatas por mais recursos [Correioweb]

b. Os EUA acusaram a Síria e o Irã de facilitarem a fuga de criminosos. [Jornal Nacional]

c. Carlão diz para Irene que ainda vai tentar convencer seus pais a voltarem para casa [Site da novela Mulheres Apaixonadas]

d. Na terça-feira, porém, Seul exortou cidadãos sul-coreanos a não viajarem ao Iraque $[O$ Globo Online $]$

e. Áudio divulgado por rede de TV se refere a atentado que matou líder xiita em mesquita e incita iraquianos a atacar colaboradores dos EUA [O Globo Online]

f. A polícia forçou os manifestantes a sair

(71) a. Três estudantes foram presos na madrugada deste sábado depois de terem disparado dois morteiros contra o prédio do Distrito Policial [O Globo Online]

b. Após gravarem suas participações finais, os atores acompanham o trabalho dos produtores [Site Babado]

c. Dois homens se envolveram em um acidente de carro após fazerem uma vítima refém em um assalto na Ceilândia [Correioweb]

d. Ladrões são presos após assaltarem Feira dos Importados [Correioweb]

e. Os meninos trancaram a casa antes de sair

f. Nós encontramos o Pedro depois de assistir ao filme 


\subsection{Generalizações propostas para o português do Brasil}

A partir da análise dos dados acima, Rabelo (2004) faz as seguintes generalizações descritivas, que levaram à conclusão de haver controle obrigatório com infinitivo não-flexionado e flexionado no português do Brasil.

\subsubsection{Oracõos infinitivas não-flexionadas}

As orações com o infinitivo não-flexionado ocorrem em construções completivas e adverbiais: nas completivas, o sujeito (nulo) da oração infinitiva pode ser controlado pelo sujeito (cf. (71b) e (71d)), ou pelo objeto da matriz (cf. (72e) e (72f)); nas adverbiais, o sujeito da oração infinitiva é sempre controlado pelo sujeito da matriz (cf. (73e) e (73f)).

Como se depreende dos dados em (74), nesse contexto, elementos com realização fonológica não podem ocupar a posição de sujeito da oração infinitiva, seja esse elemento um pronome, uma expressão-R(eferencial) ou um sintagma quantificador:

(72) a. *Os meninos tentaram eles/os amigos/todos eles sair

b. *As italianas sabem elas/as francesas/todas elas ser encantadoras

c. *Áudio divulgado por rede de TV incita iraquianos a eles/os vizinhos/ todos eles atacar colaboradores dos EUA

d. *A polícia forçou os manifestantes a eles/os grupos mais radicais/todos eles sair

e. *Os meninos trancaram a casa antes de eles/as crianças/todos eles sair

f. *Nós encontramos o Pedro depois de nós/os nossos amigos/todos nós assistir ao filme

\subsubsection{Orações infinitivas flexionadas}

As orações com o infinitivo flexionado ocorrem em construções completivas e adverbiais: nas completivas, o sujeito nulo da oração infinitiva pode ser controlado pelo sujeito (cf. (71c)), ou pelo objeto da matriz (cf. (72a)-(72d)); nas adverbiais, o sujeito da oração infinitiva é controlado pelo sujeito da matriz (cf. (73a)-(73d)). ${ }^{27}$

27 Foi-nos apontado que, apesar de a correferência ser possível nesses casos (e pragmaticamente favorecida), no dialeto dos falantes que permite pro com referência independente de um antecedente, ela não é obrigatória. 
No entanto, esse grupo distingue-se do anterior, pelo fato de que, tanto em construções completivas quanto em adverbiais, elementos com realização fonológica (pronomes realizados foneticamente (com leitura correferente ou não), expressões- $\mathrm{R}$ e sintagmas quantificadores) podem ocorrer na posição de sujeito da oração infinitiva, conforme ilustrado em (75).

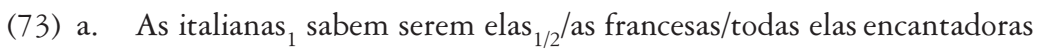

b. [Os pais da Maria $]_{1}$ admitiram morarem eles ${ }_{1 / 2} / o s$ amigos/todos eles nos EUA

c. Três estudantes ${ }_{1}$ foram presos na madrugada deste sábado depois d'eles $1 /$ dos bandidos/de todos eles terem disparado dois morteiros contra o prédio do Distrito Policial

d. Dois homens ${ }_{1}$ se envolveram em um acidente de carro após eles ${ }_{? 1 / 2} / o s$ comparsas/todos eles fazerem uma vítima refém em um assalto na Ceilândia

É interessante notar que a realização fonológica do sujeito da oração infinitiva não é possível em construções de controle pelo objeto da oração matriz, conforme ilustrado em (76), exceto quando se trata de um sintagma quantificador - que pode ser licenciado como sujeito da oração infinitiva, mantendo-se a obrigatoriedade da leitura correferente entre o sintagma quantificador e o objeto da oração matriz:

(74) a. Ministro da Educação incentiva estudantes ${ }_{\mathrm{i}}$ a todos eles $\mathrm{e}_{\mathrm{i} / * \mathrm{k}}$ fazerem passeatas por mais recurso

(cf. *Ministro da Educação incentiva estudantes ${ }_{1}$ a eles ${ }_{1 / 2} /$ os amigos fazerem passeatas por mais recursos)

b. Os EUA acusaram a [Síria e o Irã $]_{1}$ de ambos $_{1 / * 2}$ facilitarem a fuga de criminosos

(cf. *?Os EUA acusaram a [Síria e o Irã $]_{1}$ d'eles ${ }_{1 / 2} /$ d'os comparsas facilitarem a fuga de criminosos)

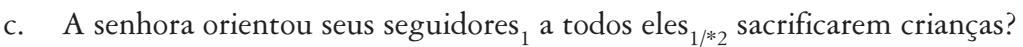
(cf. *A senhora orientou seus seguidores ${ }_{1}$ a eles ${ }_{1 / 2} /$ os criminosos sacrificarem crianças?)

Cabe, porém, observar que um sintagma quantificador é licenciado como sujeito da oração infinitiva, mantendo-se a obrigatoriedade da leitura correferente entre o sintagma quantificador e o objeto da oração matriz.

Essas generalizações levaram Rabelo (2004), em consonância com Raposo (1987) e Pires (2001), entre outros, à hipótese de que o controle no 
português ocorre no contexto de infinitivo não-flexionado, como seria esperado, já que nesse contexto o sujeito da oração subordinada infinitiva é obrigatoriamente nulo, anafórico, e o infinitivo não apresenta flexão, ou seja, apresenta as propriedades típicas das construções de controle. Entretanto, ao contrário do que tem sido proposto, levaram-na também à hipótese de que o controle ocorre em contextos de infinitivo flexionado, embora de forma mais restrita do que acontece com o infinitivo sem flexão, pois parece ocorrer apenas nos casos de controle pelo objeto, contexto em que são mantidas as características típicas do controle, à exceção de haver marcas flexionais no verbo da oração infinitiva subordinada.

A conclusão de que há controle com o infinitivo flexionado tem conseqüências importantes para a teoria do controle em geral, seja pelo fato de se considerar que existem línguas em que há a possibilidade de haver controle com sujeito pro, seja pelo fato de se considerar a possibilidade de haver um sujeito PRO em orações com flexão.

\section{Conclusão}

Cabe, nesse momento, retomar as conclusões parciais de cada uma das pesquisas apresentadas.

Na Seção 2, foi apresentado o trabalho de Lunguinho (2005), o qual demonstra que os traços aspectuais dos verbos começar, terminar e continuar interferem diretamente tanto nas restrições de seleção dos complementos desses verbos quanto nas possibilidades de combinação desses verbos na sintaxe.

Os traços aspectuais (especificamente telicidade e mudança de estado) também são relevantes, de acordo com o trabalho de Naves (2005), para explicar por que certos verbos psicológicos e causativos admitem alternância sintática, enquanto outros verbos dessas mesmas subclasses semânticas não admitem esse tipo de alternância.

Na Seção 4, com base nos trabalhos de Pilati (2002) e (2006), concluise que as orações declarativas do português, dadas as suas características sintáticas e semânticas, podem ser analisadas como inversões locativas. 
Com relação aos fenômenos de alçamento de objeto e de flutuação de quantificador no PB, discutidos na Seção 5 com base no trabalho de Vicente (2006), foi demonstrado que o movimento do objeto, no PB, não é manifesto, como no inglês e no romeno, e que o complemento de verbos passivos e inacusativos do $\mathrm{PB}$ sofre um movimento intermediário para [Spec, AgrOP].

Por fim, a Seção 6 tratou das generalizações descritivas, apontadas por Rabelo (2004), para as construções de controle, as quais levam a autora a trabalhar com a hipótese de haver controle obrigatório com infinitivo nãoflexionado e flexionado no português brasileiro.

Como foi dito na introdução deste artigo, a intenção era a de deixar transparecer, por meio da apresentação dos últimos trabalhos orientados por Lobato, um pouco da sua visão teórica. É preciso registrar que, não fosse a necessidade de produzir um texto conjunto, possivelmente esse esforço não teria sido realizado.

Por tudo isso, não há uma conclusão comum; há intuições lingüísticas e um desejo incomensurável de dar continuidade ao trabalho de pesquisa que esse grupo começou a desenvolver.

\author{
E-mails: \\ marcusvsl@unb.br \\ rnaves@unb.br \\ eloisapilati@gmail.com.br \\ poliana.rabelo@gmail.com \\ helenagv@terra.com.br
}

\title{
REFERÊNCIAS BIBLIOGRÁFICAS
}

Albiou, G. 1999. De-focusing and object raising in Romanian. Canadian Journal of Linguistics 44: 1-22.

ARAD, M. 1998. VP-structure and the syntax-lexicon interface. Tese de Doutorado. London: University College London.

Belletti, A. \& L. Rizzi. 1988. Psych-verbs and q-theory. Natural Language E Linguistic Theory 6: 291-352. 
1992. Notes on psych-verbs, q-theory and binding. In: R. FreIDIN (org.) Principles and Parameters in comparative grammar. Cambridge/ Massachusetts: MIT Press. 132-162.

Belletti, A. 2001. "Inversion” as focalization. In: A. Hulk \& J.-Y. Pollock (orgs.) Inversion in romance and the theory of universal grammar. Oxford: Oxford University Press.

Bennis, H. 2004. Unergative adjectives and psych verbs. In: A. Alexiadou, E. Anagnostopoulou \& M. Everaert (orgs.) The unaccusativity puzzle: explorations of the syntax-lexicon interface. Oxford: Oxford University Press.

Boff, R. 2003. Em busca de uma análise sintático-semântica para construções com o verbo começar no português brasileiro. Dissertação de Mestrado. Curitiba: Universidade Federal do Paraná.

Boskovic, Z. 1997. The syntax of nonfinite complementation: An economy approach. Cambridge, Massachusetts: MIT Press.

. 2004. Be careful where you float your quantifiers. Natural Language and Linguistics Theory 22: 681-742.

BOUCHARD, D. 1995. The semantics of syntax. Chicago: University of Chicago Press.

BRESNAN, J. 1994. Locative inversion and universal grammar. Language 70.1: 72-131.

Bresnan, J. \& J. Kanerva. 1989. Locative inversion in Chichewa: A case study of factorization of grammar. Linguistic Inquiry 20.1: 1-50.

BuRzIO, L.1986. Italian syntax. Dordrecht: Reidel.

CANÇADO, M. 2002. Uma aplicação da teoria generalizada dos papéis temáticos: Verbos Psicológicos. Revista do GEL Número Especial: 95125.

Castilho, A. de. 1968. Introdução ao estudo do aspecto verbal na língua Portuguesa. Alfa 12: 7-123.

. 1984. Ainda o aspecto verbal. Estudos portugueses e africanos 4: 9-36.

2002. O aspecto verbal no português falado. In: M. B. Abaurre \& A. Rodrigues. (orgs.) Gramática do português falado. Vol.VII. Campinas: Editora da Unicamp.

Chomsky, N. 1981. Lectures on government and binding. Dordrecht: Foris Publications.

. 1995. The Minimalist Program. Cambridge/Massachusetts: MIT Press. 
2001. Derivation by phase. In: M. Kenstowicz (org.) Ken Hale.

A life in language. Cambridge/Massachusetts: MIT Press. 1-52.

. 2005. On phases. Ms. Cambridge/Massachusetts: MIT.

CINQUE, G. 1993. A null theory of phrase and compound stress. Linguistic Inquiry 24.3: 239-297.

. 1999. Adverbs and functional heads. Oxford: Oxford University Press.

Cornilescu, A. 2000. The double subject construction in Romanian. In: V. Motapanyane (org.) Comparative studies in Romanian syntax. Dordrecht: Elsevier. 8-134.

Conso, S. 2002. Verbos auxiliares no português brasileiro. Dissertação de Mestrado. Florianópolis: Universidade Federal de Santa Catarina.

Costa, S. 1997. $O$ aspecto em português. $2^{\text {a }}$ ed. São Paulo: Contexto.

Costa, J. \& Charlotte G. 2002. Peripheral subjects in two varieties of Portuguese: evidences for a non-unified analysis. In: C. BEYssade, R. Bokbennema, F. Drijkoningen \& P. Monachesi (orgs.) Romance language and linguistic theory. Utretch: John Benjamins. 109-125. [Disponível em http://www.ime.usp.br/ tycho/papers/costacgalves.pdf].

CROFT, W. 1993. Case marking and the semantics of mental verbs. In: J. Pustejovsky (org.) Studies in linguistics and philosophy 49: Semantics and the lexicon. London: Kluwer Academic Publishers. 55-72.

CunHA, L. F.1998. As construções com progressivo em português: uma abordagem semântica. Dissertação de Mestrado. Portugal: Universidade do Porto. . 2004. Semântica das predicaçôes estativas: para uma caracterização aspectual dos estados. Tese de Doutorado. Portugal: Universidade do Porto.

DasCal, M. 1982. Comecemos a acabar de começar? Prolegômenos para uma análise semântica de algumas perífrases verbais indicadoras de fase, em português. Cadernos de Estudos Lingüísticos 3: 123-186.

de Swart, H. 1998. Aspect shift and coercion. Natural Language and Linguistic Theory 16.2: 347-385.

DuARTE, M. E. 1993. Do pronome nulo ao pronome pleno: A tragetória do sujeito no português do Brasil. In: I. RoBerTs \& M. Kato (orgs.) Português brasileiro: uma viagem diacrônica. Campinas: Editora da Unicamp, pp. 107-128.

Figueredo Silva, M. C. 1996. A Posição do sujeito no português brasileiro: frases finitas e infinitivas. Campinas: Editora da Unicamp.

GonÇALVES, A. 1996. Aspectos da sintaxe dos verbos auxiliares do português europeu. In: A. Gonçalves, M. Colaço, M. Miguel \& T. Moia (orgs.) Quatro estudos em sintaxe do português. Lisboa: Colibri. 7-50. 
Grimshaw, J. 1990. Argument structure. Cambridge, Massachusetts: MIT Press.

Hale, K. \& S. J. Keyser. 1998. The basic elements of argument structure. MIT Working Papers in Linguistics 32. Cambridge, Massachusetts: MIT. . 1999. Bound features, merge, and transitivity alternations. Ms., Cambridge, Massachusetts:MIT.

Herdan, S. 2003. Floating quantifiers in Romanian. Ms., Storrs: University of Connecticut. [Disponível em http://www.linguistics.uconn.edu/pdf/ eco503/herdan.pdf].

. 2005. Floating quantifiers and the structure of Romanian. University of Connecticut Working Papers in Linguistics 13:79-118.

Holmberg, A. 1999. The true nature of Holmberg's generalization. Studia Linguistica 53:1-39.

\& C. Platzack. 1995. The role of inflection in Scandinavian syntax. Oxford: Oxford University Press.

Johnson, K. 1991. Object positions. Natural Language and Linguistic Theory 9: 577-636.

Kato, M. 2000. A restrição de mono-argumentalidade da ordem VS no português do Brasil. Fórum Lingüístico 2: 97-127.

\& F. Tarallo. 2003. The loss of VS syntax in Brazilian Portuguese.

In: B. Schlieben, I. Koch \& K. Jungblut (orgs.) Dialog zwischen den Schulen. Münster: Nodus Publikationen. 101-129.

LACA, B. 2004. Romance "aspectual" periphrases: eventuality modification versus "syntactic" aspect. In: J. Guerón \& J. LeCARME (orgs.) The syntax of time. Cambridge, Massachusetts: MIT Press. 425-440.

LASNIK, H. 1999. Minimalist analysis. Oxford: Blackwell.

2000. Subjects, objects, and the Extended Projection Principle. Stanford Linguistic Colloquim. [Disponível em http://www.stanford.edu/ dept/linguistics/colloq]

Lemle, M. 1984. Análise sintática. São Paulo: Ática.

Levin, B. 1993. English verb classes and alternations: A preliminary investigation. Chicago: University of Chicago Press.

\& M. H. RAPPAPORT. 1995. Unaccusativity at the syntax-lexical semantics interface. Cambridge, Massachusetts: MIT Press.

Lobato, L. 1971. L'auxiliarité en langue Portugaise. Tese de Doutorado. Paris: Université de Paris III.

. 1975. Os verbos auxiliares em português contemporâneo: critérios de auxiliaridade. In: L. LoBATO et alii (orgs.) Análises lingüísticas. Petrópolis: Vozes. 
Longo, B. 1990. A auxiliaridade e a expressão do tempo em português. Tese de Doutorado. Araraquara: Universidade Estadual Paulista. \& O. Campos. 2002. A auxiliaridade: perífrases de tempo e aspecto no Português falado. In: M. B. Abaurre \& A. Rodrigues (orgs.) Gramática do português falado. Vol.VII. Campinas: Editora da Unicamp. Lunguinho, M. V. 2005. A ordem dos verbos auxiliares: Uma análise em termos de traços. Dissertação de Mestrado. Brasília: Universidade de Brasília. Mateus, M. H. M., A. M. Brito, I. Dutarte, I. Faria, S. Frota, G. Matos, M. Vigário \& A. Villalva. 2003. Gramática da língua Portuguesa. $5^{\text {a }}$ edição revista e aumentada. Lisboa: Caminho.

Naro, A. \& S. Votre. 1999. Discourse motivations for linguistic regularities: verb/subject order in spoken Brazilian Portuguese. Probus 11.1: 76-100.

Nascimento, M. do. 1984. Sur la postposition du sujet dans le Portugais du Brésil. Tese de Doutorado. Paris: Université de Paris VIII.

NAVEs, R. R. 2005. Alternâncias sintáticas: questões e perspectivas de análise. Tese de Doutorado. Brasília: Universidade de Brasília.

Negrão, E. 1986. Anaphora in Brazilian Portuguese complement structures. Tese de Doutorado. Madison: University of Wisconsin.

Oliveira, F. 2003. Tempo e aspecto. In: M. H. Mateus et alii (orgs.) Gramática da língua portuguesa. Lisboa: Caminho. 127-178.

Oliveira, F., L. F. Cunha, S. Matos \& A. Gonçalves. 2001. Verbos de operação aspectual em PE e em PB: semântica e sintaxe. Boletim da Abralin 26/ Especial: 380-385.

Pesetsky, D. 1995. Zero syntax: experiencers and cascades. Cambridge, Massachusetts: MIT Press.

Pilati, E. 2002. Sobre a ordem verbo-sujeito no português do Brasil. Dissertação de Mestrado. Brasília: Universidade de Brasília.

.2006. Aspectos sintáticos e semânticos da ordem verbo-sujeito no português do Brasil. Tese de Doutorado. Brasília: Universidade de Brasília.

PINTO, M. 1997. Licencing and interpretation of inverted subjects in Italian.

Tese de Doutorado. Utrecht: LEd.

RABelo, P. 2004. Sobre a questão do controle no infinitivo flexionado do Português. Dissertação de Mestrado. Brasília: Universidade de Brasília.

RADFORD, A. 1997. Syntactic theory and the structure of English. Cambridge: Cambridge University Press.

Raposo, E. 1989. Propositional infinitival constructions in European Portuguese. In: O. JAeggli \& K. SAfir (orgs.) The Null Subject Parameter. Dordrecht: Kluwer. 277-305. 
ReInHART, T. 1995. Interface strategies. Ms., OTS, Universidade de Utrecht. .2000. The theta system: syntactic realization of verbal concepts. OTS Working Papers in Linguistics.

2001. Experiencing derivations. In: R. HASTINGS, B. JACKSON \& Z. Zvolensky (orgs.) Proceedings from Semantics and Linguistic Theory. Ithaca: CLC Publications.

Roussou, A. (no prelo). In the mood for control. University of Patras.

Sмith, C. 1983. A theory of aspectual choice. Language 59.3: 479-501. . 1991. The parameter of aspect. Dordrecht: Kluwer Academic Press.

SPORTICHE, D. 1988 A theory of floating quantifiers and its corollaries for constituent structure. Linguistic Inquiry 19.3: 425-449.

TALMI, L. 1985. Lexicalization patterns: semantic structures in lexical forms. In: T. SHOPEN (org.) Language typology and syntactic description. Vol. III: Grammatical categories and the lexicon. Cambridge: Cambridge University Press. 57-149.

Tenny, C. 1987. Grammaticalizing aspect and affectedness. Tese de Doutorado. Cambridge, Massachusetts: MIT. . 1989. The aspectual interface hypothesis. Lexicon Project Working Papers 31. Cambridge, Massachusetts: MIT Press.

\& J. Putejovsky. 2000. A history of events in linguistic theory. In: C. Tenny, Carol \& J. Putejovsky (orgs.) Events as grammatical objects: the converging perspectives of lexical semantics and syntax. Stanford: CSLI Publications. 3-37.

VendLer, Z. 1967. Linguistics in philosophy. Ithaca: Cornell University Press. VerkuYl, H. 1999. Aspectual issues: studies on time and quantity. Stanford: CSLI Publications.

VICENTE, H. G. 2006. O quantificador flutuante "todos" no português brasileiro e no inglês: Uma abordagem gerativa. Tese de Doutorado. Brasília: Universidade de Brasília.

VIKNER, S. 1995. Verb movement and expletive subjects in germanic languages. Oxford: Oxford University Press.

W ACHOWICZ, T. C. Auxiliary and aspectualizer verbs: some syntactic and semantic distinctions. Ms., Universidade Federal do Paraná.

\& S. CAVALLI. 2006. Verbos auxiliares vs. verbos aspectualizadores. Comunicação apresentada no $54^{\circ}$ Seminário do GEL. Araraquara: Universidade Estadual Paulista. 